\title{
The Markets for Disaster Insurance
}

\author{
by Guillermo Gallardo *
}

This paper refers to three countries which have concerned themselves with finding solutions to the consequences of natural disasters on the national economy.

These three countries are: Spain, which has legislation on disaster insurance through the Consorcio de Compensación de Seguros (Insurance Compensation Syndicate), which I mention here mainly because the "Regulations of the Insurance Compensation Syndicate" and the "Exceptional Risks Insurance" are being submitted for amendment at this time ; the United States of America, which has legislation on the coverage of flood damage ; and lastly, Costa Rica, which has for some years sought to protect harvests by means of an integral insurance administered by the Instituto Nacional de Seguros (National Insurance Institute).

\section{Definition of disaster}

Of the natural disasters which affect the national economy perhaps the best-known is earthquake, but I shall not touch on this subject since it has been widely discussed in various national and international forums.

Disasters may be of human or natural origin.

The first category includes those usually described as resulting from human error : aircraft accidents, train crashes, etc.

Natural disasters fall outside this group. Their commonest forms are : storms, floods, drought, earthquakes ; they are always caused by atmospheric or tectonic disturbances.

Whatever the type of disaster, it always results in loss to the national economy and the country concerned has to bear the consequences.

According to statistics kept by various international organizations, some 400 major natural catastrophes with significant effects on national economies have occurred this century.

\footnotetext{
* Instituto Nacional de Seguros, Costa Rica.
} 
These phenomena were distributed as follows :

$\begin{array}{lr}\text { Floods } & 52 \% ; \\ \text { Earthquakes } & 17 \% ; \\ \text { Hurricanes } & 15 \% ; \\ \text { Drought } & 7 \% ; \\ \text { Volcanic eruptions } & 3 \% ; \\ \text { Others } & 6 \%,\end{array}$

In the early years of the century, there were only some 3 disasters per year, but this number has increased to 15 today. The main cause for the increase are :

(a) Growth of the world's population;

(b) Concentration of the population and resources in the cities ;

(c) Higher level of living;

(d) Urbanization and industrialization of business ;

(e) More hazardous technology.

It should be borne in mind in this connection that, in a trend that is most marked in developing countries, the number of cities with more than a million inhabitants will double from 200 to 400 and the number of those with over 10 million will rise from 10 to 25 by the year 2000 .

Because of the changes which have taken place, disasters are causing steadily greater losses. That is why countries have placed emphasis on setting up systems to mitigate such effects.

\section{Spain : the Insurance Compensation Syndicate}

The beginnings of this group are described in the publication Entre Ficción y Realidad (Between Fiction and Fact) by the Compañía Suiza de Reaseguros, which is summarized hereunder.

At the end of the 1936-1939 war, the (Life) Insurance Compensation Syndicate was set up under an Act of 17 May 1940, as the first official means in the sphere of life insurance for dealing with exceptional disasters. By a Ministerial Order of 19 February 1940 , insurance companies dealing with fire, burglary and riots were required to give an account of all the claims made between 18 July 1936 and 1 April 1939; The Riot Risk Compensation Syndicate was then set up under an Act of 24 June 1941.

The Act of 17 October 1941 brought into being the Individual Accident Compensation Syndicate.

On 5 May 1944, a Decree suppressed the Syndicate for Disaster Risk Compensation in relation to Property.

On 15 June 1954, a Ministerial Order suppressed the (Life) Insurance Compensation Syndicate. The final stage in the constitution of a guarantee against disaster risks occurred with the Act of 16 December 1954, which established a new system of coverage by merging the Syndicate for Disaster Risks Compensation in relation to Property and the Personal Accidents Syndicate in a single body called the Insurance Compensation Syndicate. 
The grounds for this move were: the high rate of disasters of an exceptional nature and the influence of this group among Spanish insurers. Furthermore, also the fact that, owing to their magnitude and extent, such risks cannot at present be covered by private initiative. This is without prejudice to their coverage by private insurance when experience shows that to be desirable.

The Insurance Compensation Syndicate, a body responsible to the General Directorate for Insurance and Savings (with full legal personality), is the insurer.

It has three sections : Property risks ; Personal risks ; Crop-growing, forestry and stock breeding risks.

All policies contain a clause guaranteeing the coverage of exceptional risks ; the risks covered include :

... volcanic eruptions, earthquakes, landslides, other seismic phenomena...

... In order for the damage caused by an earthquake to be eligible for reimbursement, the National Seismographical Service must determine, in the light of the seismographical observations made by the Centre or the effects caused, that the intensity of that earthquake in the disaster area was not less than grade 7 on the Wood-Neumann scale...

Exclusions: Disasters described by the authorities as "a national catastrophe or calamity ". The Insurance Compensation Syndicate may request that an event be declared a "national catastrophe or calamity". If the authorities make such a declaration and provide economic assistance to the insured affected, compensation shall be paid according to the rates in force, applying the reduction co-efficient established by the Ministry of Finance at the suggestion of the Syndicate ${ }^{1}$.

The risks for which compensation will be paid under non-personal insurance are confined to material damage which is directly or the inevitable result of exceptional causes, such as: floods, earthquakes, volcanic eruptions, landslides, avalanches or mudslides, damage caused by hail, wind, snow or rain, the fall of heavenly bodies and meteorites; generally speaking, damage caused by catastrophes which are exceptional in their consequences and their lack of periodicity will also be covered.

Obviously, the events concerned must have occurred on Spanish territory.

Article 6 defines in its various paragraphs the risks covered which are catastrophic and the result of natural changes.

It determines how cases of repetition should be treated ; the most important aspect is perhaps that the article allows the insurer to call for the taking of preventive measures, for the payment of an increased charge for protection and even for the suspension of coverage.

In cases of the obvious repetition of disasters, it is open to the Insurance Compensation Syndicate to demand an increase in the extra premium, the adoption by the insured of specific preventive measures, or the suspension of the coverage for exceptional risks.

1 Entre Ficción y Realidad, algunos planes para mitigar los efectos de las catástrofes, Compañia Suiza de Reaseguros. 
Flood damage is reimbursable at a rate of 100 per cent if it occurs more than 300 metres from the river bed or at a height of more than 7 metres, 60 per cent when the distance is less than 300 metres but the height more than 4 metres, and lastly, 40 per cent in all other cases. These percentages apply when the things insured have been affected by flooding from rivers and even if the flooding coincides with exceptionally heavy rain.

If the insured so wishes, he may request the non-application of the coefficients by payment of a supplement. There is no limit for risks arising from natural disturbances, and the only exclusions are : (a) civil or international war; (b) damage due to inherent defect ; (c) damage deriving from nuclear power ; (d) damage affecting goods - even goods expressly included in the policy - which are not in isolation, considered susceptible to damage from the ordinary risk provided for in the policy; (e) damage affecting goods insured under shipping or air freight policies, or for all risks in construction, engineering, assembly and testing; (f) the risks covered by third party liability insurance.

The sum payable is subject, in advance, to a deductible of 3 per cent (minimum : 10,000 pesetas).

All policies must have a validity of at least 30 days before the right to claim can be exercised.

If the sum insured is less than the value of the interest insured when compensation is paid, the corresponding co-insurance shall be applied.

\section{The new regulations of the Insurance Compensation Syndicate}

I feel I should clarify the scope of the new regulations of the Insurance Compensation Syndicate, the objectives of which are :

To update the previous Regulations of 13 April 1956 as amended by Decree on 28 November 1963 and set out pursuant to the Act of 16 December 1964, and to incorporate the new duties entrusted to the Syndicate by Act 25 of 29 April 1964 on nuclear power; Act 81 of 5 December 1968 on forest fires ; Act 10 of 4 July 1970 on export credit insurance; Act 87 of 28 December 1978 on combined agricultural insurances; and Royal Decree 2878 of 13 November 1981 on the merging of the independent bodies linked to the General Directorate of Insurance. The new regulations have brought the structure of the organization into line with its new tasks.

The Insurance Compensation Syndicate has full legal personality and capacity to pursue its objects ; it is answerable to the General Directorate of Insurance and comes under the supreme authority of the Minister of Finance.

It is a public law organization, as provided for in article 5 (D) of the Autonomous State Bodies Act of 26 December of 1958, and pursuant to the provisions of Article 83 and concordant articles of the General Budget Act. It was classified under Royal Decree 2511 of 19 September 1977 as an independent organization of a commercial, industrial or financial nature.

In matters which do not come under administrative law, it is governed by the rules of ordinary law, and, as provided in the Administrative Procedures Act, any civil or labour claim which has to be pursued against the Syndicate through the courts must first be exhausted before it can be taken up through administrative channels. 
All operations it performs are exempt from all forms of taxation and the payment of indemnities.

Part of the liability assumed may be ceded or retroceded to such Spanish companies or foreign reinsurance institutions as the Syndicate's Governing Council considers most appropriate.

The Insurance Compensation Syndicate performs the following duties :

(a) It covers exceptional risks ;

(b) It participates in the coverage of nuclear risks ;

(c) It covers or shares in covering crop-growing, stock-breeding and forestry risks.

Where the exceptional risks insurance is concerned, the Syndicate covers, within the limits laid down in the Regulations of this Insurance, damage from abnormal causes or causes of an exceptional nature.

With regard to crop-growing and stock-breeding risks, it is important to note that the Syndicate can undertake the following coverage and functions :

"(a) To act as mandatory reinsurer in the form and for the amount determined by the Ministry of Finance with regard to all risks provided for by Act 87 of 28 December 1978 on Combined Agricultural Insurances and included under the respective Annual Insurance Plans ;

(b) To monitor loss assessment with a view to the more efficient performance of its role as a reinsurer to adopt the measures of exclusion referred to in article $27 / 3$ of the Regulations for Combined Agricultural Insurance, adopted by Royal Decree 2329 of 4 September 1979 ;

(c) When the Government so agrees, to undertake, in a subsidiary capacity, the handling of direct insurance in the situations provided for in article 43 of the above-mentioned Regulations ;

(d) To reinsure output and risks not contracted for under the Annual Agricultural Insurance Plan, but susceptible, in accordance with the provisions of article 4 of the Regulations for Combined Agricultural Insurance of 14 September 1979, to open cover. In open coverage of stock-breeding risks, the reinsurance function is restricted to the risk of death or non-utilization of the insurance."

The administrative structure comprises : individual and collegiate organs. The former are made up of: the Chairman, the Vice-Chairman and three Directors. The collegiate organs are: the Governing Council of the Syndicate and the Governing Boards for the following types of insurance: (a) exceptional and nuclear risks ; (b) agricultural risks ; (c) export credit ; (d) traffic and hunting risks ; and (e) compulsory travellers' insurance.

The operating advisory bodies are : the Tariffs Commission and the Optional Board. There are also central and territorial administrative units. The central units have the following departments : coverage under voluntary insurance, including exceptional risks, agricultural, nuclear and export credit insurance ; and compulsory insurance, including third party liability for motor vehicles and hunting and compulsory accident insurance for travellers. 
The Technical and Financial Directorate takes in actuarial studies, data processing, administrative resources and claims.

The Financing and Investment Service takes in economic resources and investments.

There is also a Co-ordinating Directorate which includes the following departments : budget, cashier's office, supplies, general affairs, personnel, registry, inspection, branch offices, medical service and assessors unit, as well as the general secretariat of the Syndicate.

The territorial administrative units are the provincial Branch offices which constitute the outer structure of the Syndicate.

Both the directors and chiefs of service are appointed by the Minister of Finance, following proposal by the Director-General of Insurance.

It is important to mention that the Syndicate has available for the pursuit of its objects both ordinary and special economic resources including supplements on premiums or insured sums, premiums and quotas when it is the direct insurer; a percentage of the State subsidy required to set up the Stability fund ; the revenue from penalties and from its own capital, the sums recovered following the repetition of disasters, and, lastly, any income which it may obtain from any other source.

It also has special economic resources when the financial situation so requires, in accordance with the provisions of article 113 of the General Budget Act, article 7 of the Act of 16 December 1954 and article 8 of Decree Law 18 of 13 October 1964. It may arrange credit with the Banco de España and issue bonds aimed, under set conditions of security, interest and reimbursement, at the public in general and at insurance firms in particular.

Loadings and premiums are calculated in accordance with the tariffs approved by the Ministry of Finance. These tariffs may be amended depending on statistical results, again with the approval of the Ministry of Finance.

\section{United States of America - The National Flood Insurance Programme}

In the United States, floods cause annual losses of over $\$ 1.5$ billion; they are associated with hurricanes which also cause heavy losses. This means that it was not easy to find insurance for these risks until the National Flood Insurance Programme was devised; in fact, a kind of negative selection process applied when persons exposed to these risks sought protection, since it could be obtained only at very high rates and with considerable restrictions.

The interest in flood insurance was more keenly felt after a tragedy, but it would then disappear with the waters which caused the disaster.

During 1951, when great expanses of Kansas and Missouri were flooded, President Truman submitted to Congress a proposal to set up a flood insurance scheme, but this move and a further attempt in 1952 were unsuccessful. 
In 1956, President Eisenhower sent Congress another proposal to set up a five-year insurance programme with subsidies for tariffs and reinsurance, and the "Federal Flood Indemnity Act ", including $\$ 2.9$ billion of economic support, was approved.

The insurance was intended to protect residences of up to $\$ 10,000$ and businesses of up to $\$ 250,000$. The plan was for the Federal and State Governments to provide a 40 per cent subsidy for premiums and for private companies to sell and service the insurance.

Although this plan was approved by Congress, it did not come into operation because the necessary budgetary allocations were not forthcoming. Flood risk therefore remained uninsured.

In 1967 , a proposal for a flood insurance scheme was submitted jointly by the Federal Government and the private insurance industry, and the National Flood Insurance Programme was signed by President Lyndon B. Johnson in 1968 as part of the Housing and Urban Development Act, which includes the National Flood Insurance Act.

The Act authorizes the establishment of a flood insurance programme which covers the entire country and resulted from the joint efforts of the Federal Government and the private insurance industry.

The Federal Insurance Administration was set up in the Department of Housing and Urban Development to run the programme and a pool of insurance companies was created to implement it.

Initially, demand for this insurance was slow, and only 90,000 flood policies were issued, for a value of $\$ 1.4$ billion.

At present there are approximately two million policies covering properties for a total value of $\$ 100$ billion.

This programme came to an end on 30 September 1982 ; there was a desire to extend it for two years, but the Democrats only wished to do so for one.

Mr. Jeffrey S. Bragg, Federal Insurance Administrator, said that " in order to ensure the continuity of the programme, we are recommending two years' extension instead of one ". He also said that much progress had been made in testing the efficiency of the operation using an actuarial basis for calculating the premiums.

The tariffs were increased by an average of 61 per cent as from January 1981 and on 1 October there was a first increase of an average of 47 per cent in the subsidised tariffs. The comment made was that action was being taken to put the programme on a sound actuarial footing by 1988 .

The Federal Insurance Administration would like to see more participation in the flood insurance programme.

Mr. George K. Bernstein, the Federal Insurance Administrator, has said that "it is no surprise that the programme has paid out over a billion dollars on claims, not counting significant additional engineering, planning and administrative costs, and that this exceeds premium income".

The policy gives the following protection : 
Emergency Programme (with subsidised premiums)

Houses, one-family

Other residential buildings

Other structures

Small businesses

Regular Programme

Houses, one-family

Other residential buildings

Other structures

Small businesses
Building

$\$ 35,000$

100,000

100,000

100,000

185,000

250,000

200,000

250,000
Contents

$\$ 10,000$

10,000 per unit

100,000 per unit

100,000

60,000

60,000 per unit

200,000

300,000

If a community of the Emergency Programme joins the Regular Programme, the sum insured can be increased by means of an endorsement, subject to a waiting period of one day.

The minimum sum of cover under the Programme are :

- Buildings with one to four dwelling units : $\$ 7,500$ on buildings ; $\$ 3,000$ for contents ;

- Others, with one to four dwelling units : $\$ 10,000$ on buildings ; $\$ 5,000$ for contents ;

- Contents for tenant : $\$ 3,000$.

The policy establishes a compulsory deductible of $\$ 200$ or 2 per cent of the sum insured, whichever is greater, for damages to structure and to contents alike.

The tariffs generally charged are $\$ 0.40$ to $\$ 0.50$ per $\$ 100$ on buildings and $\$ 0.50$ to $\$ 1$ per $\$ 100$ on contents.

Lastly, the policy describes a flood as :

A generalized temporary situation of partial or complete inundation of normally dry land owing to :

1. overflow of water or to waves ;

2. the unusual and rapid accumulation or draining off of water of whatever origin ; or

3. landslides caused or precipitated by the accumulation of surface or ground water.

The collapse of caving-in of land along the shore of a lake or other body of water which results from erosion or undermining by waves or the departure of water from its normal cycle and causes flooding as defined in point 1 above.

\section{Costa Rica - The Integral Harvest Insurance}

\subsection{Background}

Costa Rica is a small Central American country with no significant mineral resources. Much of its territory, however, comprises rich agricultural land irrigated by rivers. It can perhaps be said that Costa Rica's most valuable natural resources are its water and fertile land. 
In view of the above, the country's economy has basically been built on farming, encompassing the production of staple foods for the population, the creation of vital exports - coffee, bananas and sugar - and the development of the various types of timber existing in its many forests and some raw materials for industrial production.

Support for agriculture has been traditional in Costa Rica. It has for the most part been based on appropriate credit machinery and on official support prices, in particular for the staple food crops in the national diet and crops which generate foreign exchange.

Given the above policies, there was considerable concern in the country when it was observed that there was no mechanism to protect the farmer against natural adversities. Crops were being lost for reasons outside human control, so thwarting all the efforts put into their cultivation and creating frustration and misery among farmers, whose only recourse was to request the national banks to adjust their debts accordingly in the hope that the next harvest would make it possible to pay them off.

Faced with this situation, the National Insurance Institute (Instituto Nacional de Seguros, the country's only insurance institution, which has had a State monopoly since 1924) took steps in the mid 1950s to set up a technical commission to make the necessary studies for introducing an agricultural insurance scheme. This working group was advised by FAO and study tours were made to Puerto Rico, Mexico and the United States of America, then the only countries in America having systems of the kind in question.

In October 1957, the National Insurance Institute sent the study and its conclusions and recommendations to the Legislative Assembly of the Republic for consideration.

Congress rejected the bill since there were serious financial obstacles to the implementing of an undertaking of such importance in the immediate future.

In 1962, the bill was reactivated, again with negative results because the resources could not be obtained form the State to offset the likely losses in an area with such a high anticipated disaster rate.

In 1967, a new bill was drawn up, but it was not promulgated owing to various restrictions existing at that time.

The various efforts created steadily greater awareness of the issue among politicians and a suitable environment for launching an agricultural protection programme. Came 1969, when a seminar on insurance for crop-growing and stock-breeding was held in Santiago, Chile, and attended by technicians from the National Insurance Institute and other persons with links with national policy.

During the seminar, technical and operational aspects of this insurance were discussed in detail, and the participants decided, in various resolutions, to seek the creation of an insurance project covering the whole of Latin America.

The conclusions of the Santiago seminar were included in the project file and a deputy, who had attended that meeting, brought another bill before the Legislative Assembly. This was rigorously analysed not only by the Legislative Assembly itself but also by various Costa Rican ministries and the national banks (in Costa Rica, the commercial banks were nationalized in 1949). 
All the amendments, comments, and views on this very important bill were brought into line and introduced into the instrument that was finally promulgated as Act No. 4461 of 12 November 1969.

This Act was regulated by Executive Decree No. 70 of 16 April 1970. ${ }^{2}$

\subsection{Objectives}

Apart from its main objective, that of covering losses on the farmer's investments, the Harvest Insurance has several other objectives :

(a) To guarantee a minimum technical level in agriculture. The requirement of the insurance that certain minimum standards of agricultural practice should be observed means that, under normal conditions, the farmer can obtain yields with an acceptable rate of return.

(b) To make credit more flexible. The insurance allows financing institutions to grant credit on more flexible conditions, for it eliminates a great part of the financial risk, by serving as the collateral for agricultural loans.

(c) To act as an instrument of production. By protecting the farmer, it stimulates him to increase production, since he runs less risk of losing his investment.

(d) To provide a planning mechanism for the agricultural sector. In view of its importance in the development of agricultural output, harvest insurance becomes a mechanism to be taken into account when farming plans are drawn up.

(e) To stabilize the farmer's income. A farmer's life commonly includes both economically good and economically bad years, depending on his output.

The Harvest Insurance constitutes a stabilizing element, since it enables the farmer to recoup his investment when it has been lost owing to natural causes beyond human control.

\subsection{Financing and coverage}

The financial support of the Integral Harvest Insurance Scheme depends on its Contingency Reserve. At present, this reserve comprises the profits, if any, on policies, 10 per cent of net profits of the National Insurance lnstitute and of the State banks in the National Banking System (before income tax) and 75 per cent of the annual liquid product of the National Insurance lnstitute. The premiums, less administrative costs, must also be taken into consideration.

At present, the crops which can be insured are : rice, beans, maize, sorghum, cotton, peanuts, soya beans and melons. The feasibility of providing insurance for forests and horticultural products is being studied.

The Harvest lnsurance covers any damage to crops resulting from natural phenomena beyond human control. From this standpoint, it is an all-natural-risks insurance.

The sum insured is determined on the basis of the direct costs of the crop, which are taken from the table of investments financed by the State banking institutions. The

${ }^{2}$ El Seguro de Cosechas en Costa Rica, Information Bulletin, Instituto Nacional de Seguros. 
maximum liability of the Institute, however, does not necessarily coincide with the sum insured, but is generally lower. The farmer therefore always participates in the loss, usually in a proportion of approximately 20 per cent.

More than 95 per cent of the insurance concerns crops financed by the banks, which is why the Institute works closely with them. The bank will not process his loan unless the farmer submits a request for insurance to the Institute; then, when the crop has germinated, the farmer requests an inspection of his fields. The technician from the Institute inspects the crops, checks that they are in good condition and then establishes an inspection certificate ; this leads to the issue of a policy in which the bank appears as collateral creditor.

Later, while the crop is growing, one or more inspections are made to check whether the farmer is following basic agricultural norms. At harvest time, the farmer must give notice of cutting, so that the technicians from the Institute can inspect the harvest and request details.

When some disaster affects the crop, the farmer must register the loss by immediate notification; if the loss occurs at harvest-time, this notification replaces the cutting notice. When it adjusts the loss, the Institute compares the costs announced in the notification of claim and the information in the inspection and progress reports with the invoices produced by the farmer as evidence of the expenditure incurred.

It is important to mention that in recent years the farmers have been urged to co-operate with us and send in monthly reports of the work performed so that the Institute can better plan its work of inspection on the basis of the information supplied by the farmer.

Under Act No. 5932 of 27 September 1976, the Harvest Insurance was extended to all national production and restricted to damage caused by natural phenomena beyond the control of the insured.

Article 2 of this Act provides that 75 per cent of the net proceeds of the insurance monopoly shall be earmarked for strengthening the Technical Contingency Reserve of the Integral Harvest Insurance, subject to the deduction of the amortization payments laid down by Act No. 6904 of 22 April 1976.

Articles 3 and 6 lay down that the Executive is authorized to issue bonds, and establish when it may do so and how they are to be managed. A transcription of these articles makes this clear:

"Article 3. The Executive is authorized to issue, through the Ministry of Finance and up to a sum of 60 million colones, bonds to be known as the "Supplementary Contribution to the Integral Harvest Insurance". These bonds shall bear interest at 6 per cent and be fully State-guaranteed".

"Article 6. The Ministry of Finance shall hand over responsibility for the issuance of the bonds authorized by this Act to the National Insurance Institute as administrator of the Integral Harvest Insurance ”.

The Institute may only employ the bonds when the other components of the Technical Contingency Reserve of the Integral Harvest Insurance have been used up, and it is 
authorized to place equal numbers with the National Insurance Institute and the National Banking System.

The Executive has undertaken to prepare through the Agricultural Council and the National Insurance Institute, a development plan for the Integral Harvest Insurance such that within 10 years total coverage of the Harvest Insurance can be issued, in keeping with the order of priorities established in the plan.

Lastly, on 29 November 1977, Act No. 6186 promulgated the Bonds Act to strengthen the Technical Contingency Reserve of the Integral Harvest Insurance established under Act No. 4461 of 12 November 1969, and the Executive was authorized to issue, through the Ministry of Finance, the sum of 200 million colones in bonds to be known as the "Integral Harvest Insurance, 6 per cent 1977 ", with a life of 20 years and an annual interest rate of 6 per cent. The bonds were to be fully State-guaranteed and the interest on them was to be exempt from all types of taxation.

The Ministry of Finance was to hand over responsibility for the issuance of the bonds to the National Insurance Institute as the administrator of the Integral Harvest Insurance, which must only employ them when the other financial resources of the Technical Contingency Reserve of the Integral Harvest Insurance have been fully used up.

The annual amount of the placement is to be determined by the development requirements of the Harvest Insurance and the indemnities to be paid to the insured. To this end, the Institute must submit to the Central Bank of Costa Rica the documents justifying those requirements, so that the Bank can establish the proportion of the placements which each commercial Bank in the National Banking System must acquire. These placements may in turn be rediscounted in the Central Bank of Costa Rica at an annual rate of interest not exceeding four per cent.

\section{Conclusions}

It may be concluded from this brief analysis of three countries concerned with protection from the consequences of disaster risks that :

Only the State can provide a complement to protection against disaster risks. The insurance companies can only contribute to mitigating losses in proportion to their capacity and, if the State did not collaborate, they would be unable to insure such risks. Some of them have such enormous sums insured that they might not be able to cope with heavy losses without international assistance. This is the case of earthquake insurance in Japan, the United States of America (San Francisco) and Venezuela (Caracas), which daily have more subscribers.

Many insurance experts have concluded and recommended that this type of risk should be considered uninsurable and that it devolves on each State to absorb the losses stemming from such disasters.

Costa Rica has a good combined solution in which the State and a State company which handles the insurance monopoly are both concerned with protecting the national economy against losses from natural disasters. 
As laid down in the Act on the net proceeds of the monopoly, 75 per cent thereof goes to strengthen the Contingency Reserve of the Integral Harvest Insurance, i.e. the profits from the sales of commercial insurance subsidize insurance, including the type on which we have commented.

This cannot be a general solution, but in the case of Costa Rica it has functioned successfully and we feel very satisfied with what has been done in this regard.

\section{BIBLIOGRAPHY}

Ante Proyecto de Reglamento del Consorcio de Compensación de Seguros, Spain.

Ante Proyecto de Reglamento del Seguro de Riesgos Extraordinarios, Spain.

C.P.C.U. Journal. Flood Insurance - 1982. Sajjad A. Hashmi. March 1982.

C.P.C.U. Journal. The National Flood Insurance Program. The Executive Authority Dispute. John J. McGonagle, Jr. March 1980.

C.P.C.U. Journal. The National Flood Insurance Program. Did the Insurance Industry Drop Out? Samuel H. Weese y J. Wesley Ooms. December 1978.

Documento Informativo sobre Seguro Cosechas. Editado por Instituto Nacional de Seguros - Costa Rica.

El Ajuste de Siniestros ocurridos por catástrofes de la naturaleza. Münchener RückversicherungsGesellschaft.

Entre Ficción y Realidad. Algunos planes para mitigar los efectos de las catástrofes. Compañía Suiza de Reaseguros.

General Insurance, Government Property and Liability. David L. Bickerlhaupt. Irwin Series in Insurance and Economic Security.

Ley de Bonos: Seguro Integral de Cosechas, 6\% - 1977 No. 6186, 29 November 1977. Costa Rica.

Ley de Seguro Integral de Cosechas No. 4461, 10 November 1969. Costa Rica.

Ley de Universalización del Seguro Integral de Cosechas No. 5932, 27 September 1976. Costa Rica.

United Nations Conference on Trade and Development, 29 September 1980.

Reglamento de la Ley de Seguro Integral de Cosechas. Decreto Ejecutivo No. 70, 16 April 1970. Costa Rica.

Sigma No. 6/Junio 1980. Compañía Suiza de Reaseguros. 